\title{
静的水平加力試験に基づく伝統的木造建築の組物の履歴モデルと剛性評価 HYSTERESIS MODEL AND STIFFNESS EVALUATION OF BRACKET COMPLEXES USED IN TRADITIONAL TIMBER STRUCTURES BASED ON STATIC LATERAL LOADING TESTS
}

\author{
藤田香織*1, 木村正彦*2, 大橋好光*3, 坂本 功*4 \\ Kaori FUJITA, Masahiko KIMURA, Yoshimitsu OHASHI \\ and Isao SAKAMOTO
}

\begin{abstract}
The aim of this research is to identify the structural performance of bracket complexes used in traditional timber structures. Static vertical and lateral loading tests and shaking table tests were performed on four types of bracket complexes with the most fundamental forms. A hysteresis model of the bracket complexes was proposed based on the results of the static lateral loading tests. The stiffness of the model was evaluated by applying the theoretical stiffness of timber perpendicular to the grain, the result of which gave a fair simulation of the observed hysteretic characteristics.
\end{abstract}

Keywords: Static Lateral Loading Test, Hysteresis Characteristics, Multi-1inear Mode1 静的水平加力試験、復元力特性、マルチリニアモデル

\section{1. 序}

わが国の伝統的な建造物の多くは木質構造である。伝統的木造建築の力 学的特徵として、大きな変形能力と高い減衰性が举げられる。そして、「組 物」と呼ばれる木材の集合体の部分がその構造特性、特に振動特性に影響 があることが従来から指摘されてきたが、関連する研究例も少なく、静 的・動的な実験に基づく定量的な検討は十分であるとはいえない。

組物とは、柱或いは台輸の上に設けられ、鉛直荷重を柱に伝達する役割 を担っている支承部分の名称である。6世紀末、仏教の伝来とともに、朝 鮮半島から渡来した技術者によって日本に伝えられたといわれ、木造の寺 院・神社建築に用いられる。斗と肘木という2 種類の部材が互いに積層し て構成され、様式・年代によってその形状は多様である。

組物の力学的特性については、木造層塔の耐震性に関連して言及される ことが多い。元暦 2 年 1185 年の地震で法勝寺に所在した日本史上最大の 塔婆建築であった九重塔が大きな被害を受けた以外では、大型の塔婆建築 の地震被害はほとんど伝えられていない文。この事実に鑑みて、木造層塔 の耐震性に関寸る考察が行われてきたが、未だ定説はなく、その考察の過 程で組物の地震時の効果が指摘されてきた。棚橋は文2、木造層塔の而震性 が高い理由として、大きな塑性変形能力に起因する、高い減衰性を举げ、 組物の大きな変形能力が地震時に振動エネルギーを吸収している可能性 を指摘している。山辺・金井は、12 基の五重塔の常時微動測定及び、強制
振動試験、地震観測を行った結果から、「五重塔の耐震性は、組物構造に よる摩擦力が振動が大きくなる程、急激に増加する性質によるところが大 きいと解釈できそうである。」指摘している文 3 。

組物の実験的研究としては、坂が法隆寺金堂の昭和大修理に伴って行っ た、一連の研究が最も早い例である。法隆寺金堂の下層 1 スパン分、 $1 / 2$ 大模型の鉛直載荷下における静的水平加力試験を行い文 4 、柱単体の傾斜復 元力に関寸る実験的研究文 5 との比較から、胴張り・頭貫・組物がある丸柱 は、普通の丸柱と比較すると、引き倒し抵抗力と復原力の差 (吸収率) が 大きい、この原因として、頭貫の摩擦抵抗、組物のエネルギ一吸収、柱の 胴張りの影響が挙げられている。更に、骨組み形式が複雑化すればこの吸 収率が大きくなり、「この性能こそ、かかる古社寺骨組み構造の動力学的 問題を取扱う上に振動の減衰作用として重要な性質で五重塔の耐震性に ついて論議される問題のうち武藤博士がこれを指摘せられている点であ る。としている。

西澤は、薬師寺大講堂の復原設計に伴って、組物を含む軸組を対象とし た一連の研究を行っている。薬師寺大講堂の組物、小壁部分 1 スパン分の 実物大部分模型の静的水平加力試験とオンライン実験（仮動的実験）の結 果から得られた履歴ループの形状が、紡鍾形の相似形に近いことから、全 ての履歴ループを無次元化し、3次元関数で近似した正規化ループとした 履歴モデルを提案している。提案した履歷モデルを用いて、地震応答解析
*1 東京都立大学工学研究科建築学尃攻 講師 - 博士 (工学:

*2 東急建設技術研究所 主任研究員・工博

*3 熊本県立大学環境共生学部 助教授・工博

*4 東京大学大学院工..学系研究科建築学専攻 教授・迆博
Lecturer, Dept. of Arch., Grad. School of Eng., Tokyo Metropolitan Univ., Dr. Eng. Senior Research Engineer, Tokyu Construction, Dr. Eng.

Assistant Prof., Kumamoto Prefectural University, Dr. Eng.

Prof., Dept. of Arch., Grad. School of Eng., The University of Tokyo, Dr. Eng. 
を行い、オンライン実験結果との比較検討よりその有効性を検証している 文6。また、この履歴モデルの精度を上げ、無次元化した履歴ループを最小 二乗法で近似した多項関数式により正規化ループを求めている。更に、同 じ試験体に対して、この新しく提案された履歴モデルと、完全弾塑性型モ デル、バイリニア型モデルに関して地震态答解析を行い、オンライン実験 の結果との比較を行っている文7。これより、完全弾塑性型モデル及び、バ イリニア型モデルの解析結果はオンライン実験の結果と大きな差は認め られないが、初期剛性や線形限界点の設定に応答值が大きく左右されるこ と、より精度の高い応答值を解析的に求めるには、提案された履歴モデル による解析法が有効であることを指摘している。

林・軽部らは、平城宮跡の大極殿復原計画に伴って一連の実験的研究を 行っている文8。大極殿の初重層側通り架構、大斗上の斗組架構、1スパン 分の部分模型に関して、鉛直載荷下における静的水平加力試験を行ってい る。その結果、異なる鉛直荷重に対して降伏点に差違が認められ、結果的 に鈆直荷重が大きいほど割線剛性は大きくなっている。荷重変形関係は最 大点指向型の紡鍾形を示しており、繰り返し加力による耐力の低下は小さ い。約 $1 / 50 \mathrm{rad}$. まで水平変形した結果ダボの変形、斗の圧縮変形、斗の角 の曲け破壞などが観測されている。

以上より、組物の力学的特徴として、荷重変形関倸は紡鍾形を示す、剛 性は鈆直荷重に影響を受けることなどが上げられる。ただし、既往の研究 はいづれも特定の建物の修理或いは復原を目的としており、必ずしも一般 性が高いとはいえない。また、組物の振動時の特性として指摘されている 点に関して、その力学的機構が十分解明されているともいえない。さらに、 振動台加振試験のような動的な実験は行われていない。

本研究は、伝統的木造建築の耐震性を定量的に評価するための基礎資料
を得ることを目的として、実物大の組物 4 種類を対象とした静的水平加力 試験・振動台加振試験を行ったものである文 9 文 14 。本文では、静的水平加 力試験の結果から得られた、復元力特性及び変形の特徵に関する考察から、 組物の力学モデルにもとづいて一般的な組物の履歷モデルを提案する。振 動台加振試験の結果及び、提案した履歴モデルを用いた地震応答解析につ いては他稿で詳述する。なお、本文は文 9 、文 13 、文 14 をまとめ、加筆 修正したものである。

\section{2. 試䣯体}

試験体は、最も基本的な組物である大斗肘木、平三斗、出三斗、出組の 4 種類、各 1 体の実物大模型とした。 $2 \mathrm{~m}$ 四方の四隅に配された柱（柱頭 部分のみ高さ $70 \mathrm{~cm})$ の上に組物を設置した。形状は一般性の高いものとす るため、重要文化財建造物の寺院仏殿建築の 3 割を占める、三間堂仏殿 (図 -1）の平部分の模型とした。細部の仕様は三間堂仏殿である喜多院慈眼 堂（国指定重要文化財、川越甫）を範としている。試験体の形状・寸法と 組物の接合方法の例を（図一2）、(図ー3）にそれぞれ示した。材料は全 てヒノキとし、材料試験より単位重量及び、含水率の平均値はそれぞれ $435 \mathrm{kgw} / \mathrm{m}^{3} 、 12.1 \%$ であたた!。

\section{3. 実験概要}

実験は平成 9 年 9 月と平成 10 年 6 月に、東急建設技術研究所内の振動 台にて行った。振動台加振試験に先立って、試験体を振動台上に設置し、 鉄骨反力柱と試験体上の鉄骨治具を梁で繋ぎ、水平 1 次元正弦波（40s/1 cycle）を入力とした擬似的な静的水平加力試験を行った。上載荷重は三 間堂仏殿数棟について柱の軸力を概算した結果、檜皮莫きに相当する柱 1

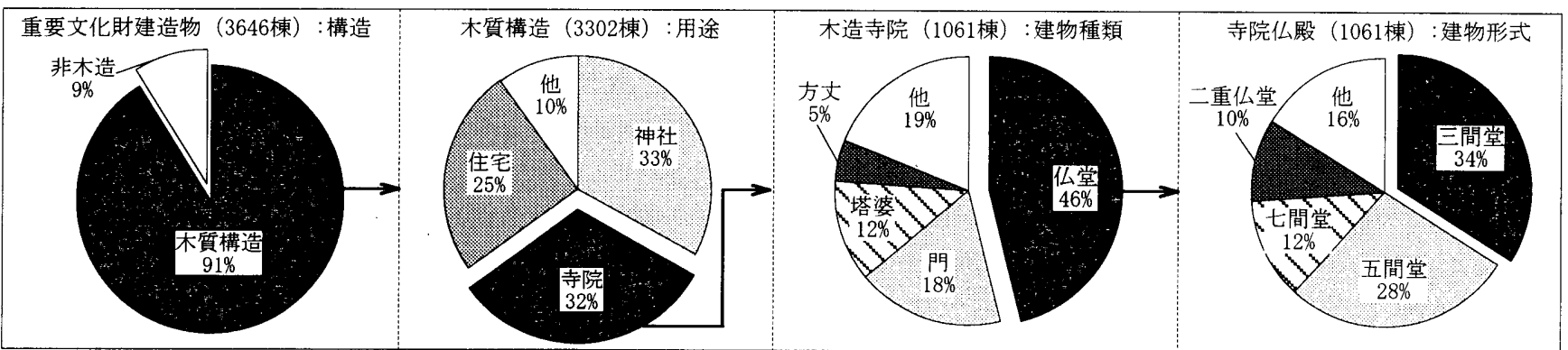

図-1 国宝・重要文化財建造物の構成（1996年現在）

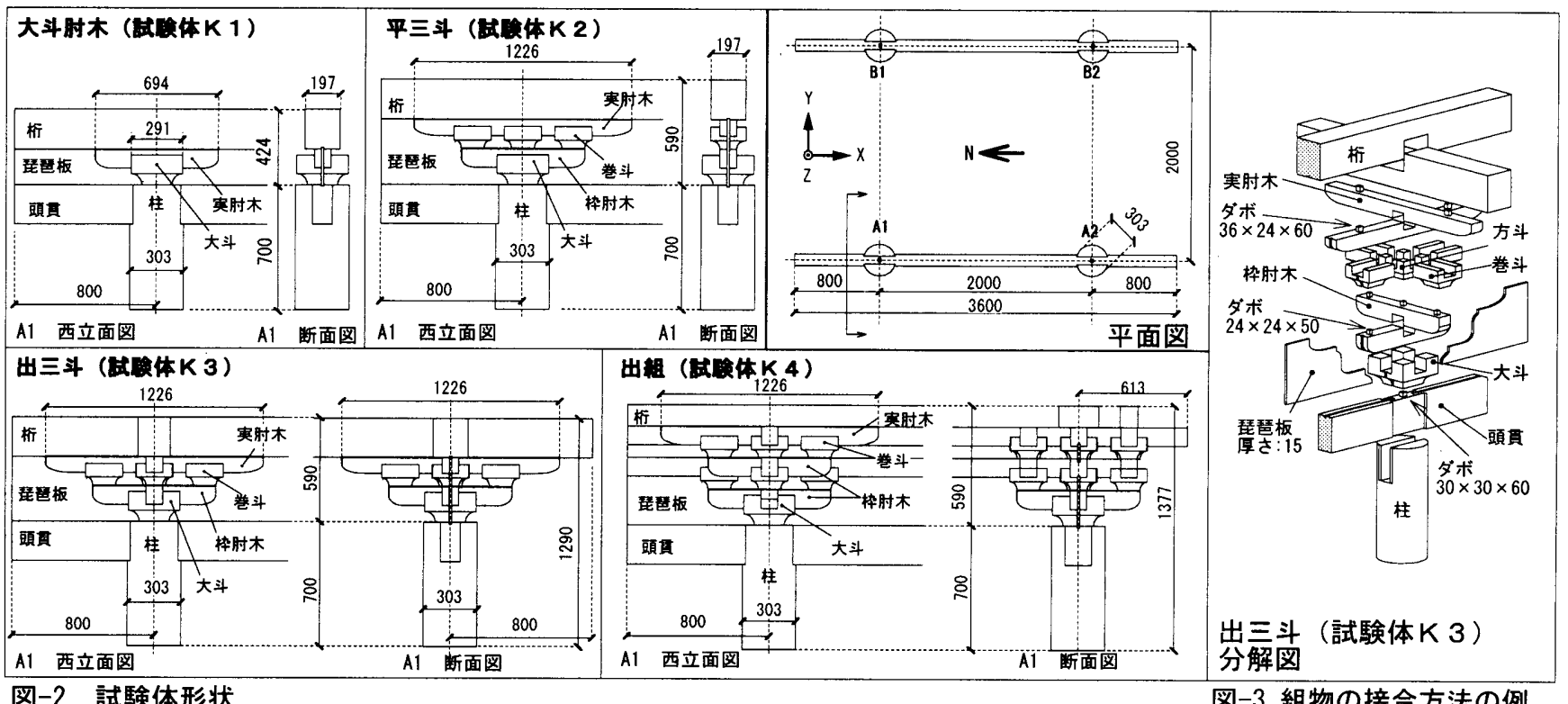

図-2 試験体形状

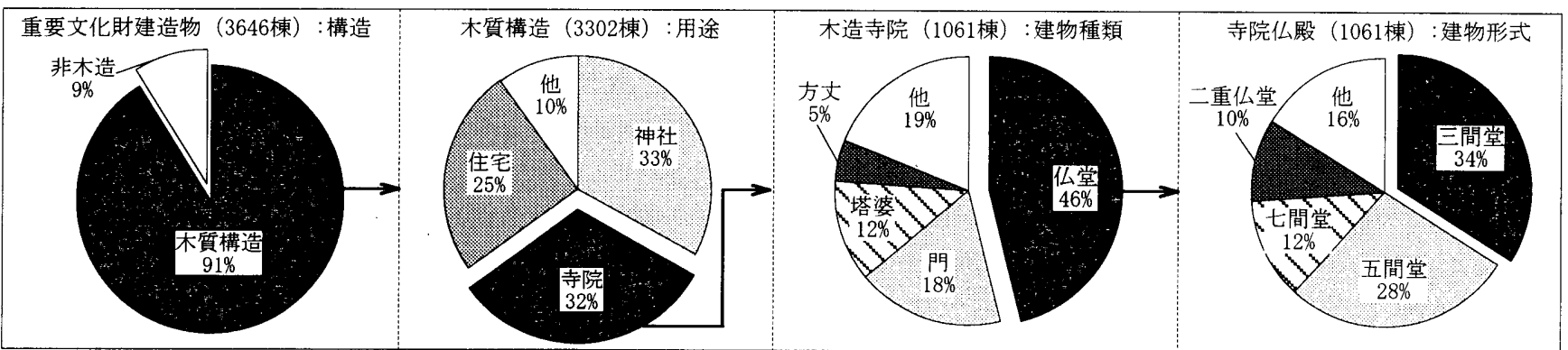


本当たり 0.5 tonf（全 2tonf）とした。水平荷重は、鉄骨治具と反力柱の 間に設置したロードセルで測定した (図ー4)。

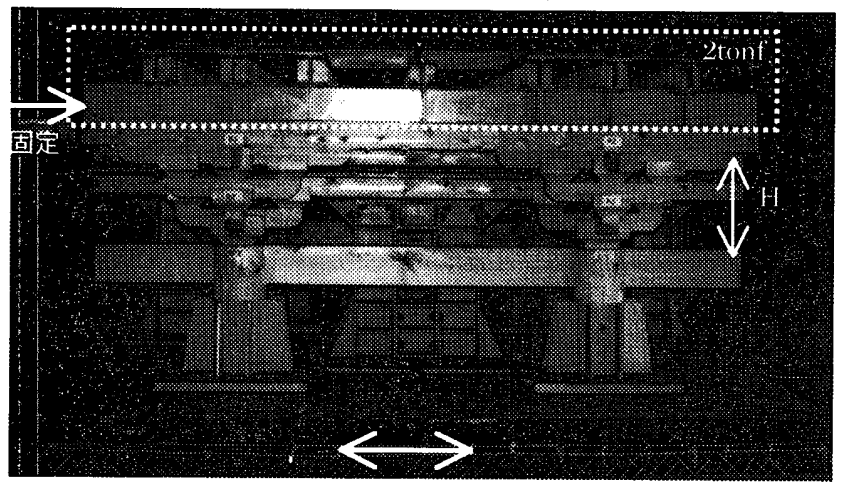

図一4 静加力試験方法

\section{4. 復元力特性}

各圾験体の荷重変位履歷曲線を図ー5に示した。ただし、試験体の水平 変形は、試験体ごとの高さが異なる点と、組物以外の変形（柱のがたなど） を除外する目的で、柱上から桁下の変形角 $\theta$ で表した。ここで、 $\theta$ は下式 のように、桁の振動台からの相対水平変位 $\left(\delta_{\text {嫩 }}\right)$ と柱頭と振動台の相対 水平変位 $\left(\delta_{\text {柱 }}\right)$ 、及び柱上面と桁下面の距離 $(\mathrm{H})$ から算出した。

変形角 $\theta=\frac{\delta_{\text {䉼}}-\delta_{\text {柱 }}}{\mathrm{H}}(\mathrm{rad}$ )

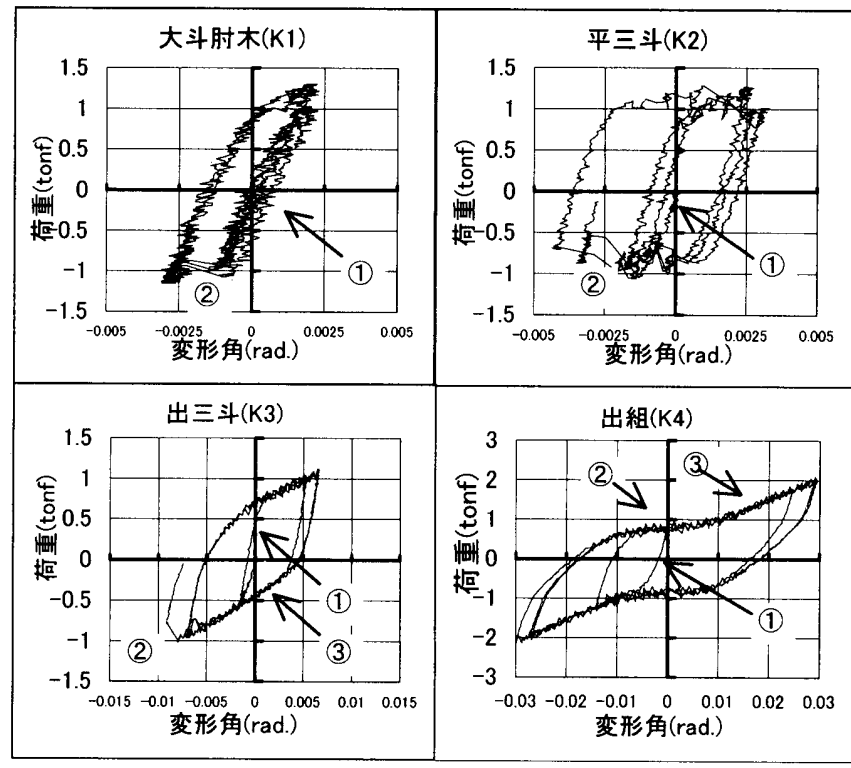

図一 5 組物試験体の荷重変位履歴曲線

組物試験体の荷重変位履歷曲線の特徵は以下のとおりである。

・折線（1)（3)）で近似できる、マルチリニア型の復元力特性を示す。

・水平荷重約 1 tonf で滑りが生じる。この值は、静摩擦力であると考えら

れ、静摩摖係数にして 0.5 であり、乾燥木材どうしとしてはほぼ妥当な值

であるといえる文9、文13

・滑りはじめると荷重が低下する傾向が認められるのは、静摩擦力>動摩 擦力のためであると考えられる。

・変形角 0.01rad. 以内では、(1)初期剛性一(2)滑り（約 1tonf）と、概衩バ イリニア型の復元力特性を示す。

・変形角 $0.01 \mathrm{rad}$. を超えると（試験体 K4 のみ）(3)第三剛性が現れ、これ は初期岡性よりも低い值である。
・いずれの試験体も、繰り返し加力に対して岡性の低下が認められない。

\section{5. 履歴モデル}

4 種類の組物の静的水平加力試験から得られた荷重变位履歴曲線の特 徵から、組物の復元力特性をその種類によらず図一6のようなマルチリニ ア型のモデルで近似する。

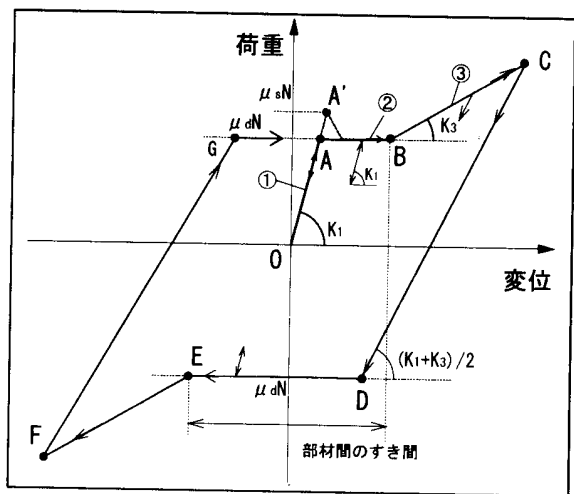

図一6 組物履歷モデル

(1) $\mathrm{O} \Leftrightarrow \mathrm{A}$ (第一剛性 $\mathrm{K}_{1}$ ): A点の荷重は動摩擦力、 $\mathrm{A}^{\prime}$ 点は静摩擦力と する。A’かはすぐ $\mathrm{AB}$ 上へ移行する.

(2) $\mathrm{A} \rightarrow \mathrm{B}$ （第二剛性 $\mathrm{K}_{2}=0$ ）: 水平力は一定（動摩擦力）であり、水平 変位のみ増え、部材間の滑りが主要な水平変位の要素である。B点は部材 間の寸き間の総量で決まる值であり、実験からは $\mathrm{A} \rightarrow \mathrm{B}$ は約 $4 \mathrm{~mm}$ であった。 $\mathrm{AB}$ 間での除荷剛性は $\mathrm{K}_{1}$ とする.

(3) $\mathrm{B} \rightarrow \mathrm{C}$ (第三岡性 $\mathrm{K}_{3}$ ): C点の上限值は本実験からは求まっていない。

- $\mathrm{C} \Leftrightarrow \mathrm{D}$ : 除荷の剛性は第一剛性と第三剛性の平均值と仮定する。

・ $\mathrm{D} \rightarrow \mathrm{E}$ : 部材間の滑り。E点はB点と同様。

ただし、大斗肘木、平二斗がバイリニア型の復元力特性を示しているの は、水平変位が $0.005 \mathrm{rad}$. 未満であり、履歴モデルの $\mathrm{O} \rightarrow \mathrm{A} \rightarrow \mathrm{B}$ までしか 現れていないためであると仮定した。出三斗に関しては、振動台加振試験 では(1)・(2)、(3)とモデルと同様の履歷形状を示していることから文い、静加 力試験の際には滑りが生じる前に大斗と斗の回転によりダボのめり込み が一部発生した可能性が考えられる。

\section{6、変形の特徽}

組物の荷重変位履歷曲線をマルチリニア型の履歴モデルで近似した。次 に、各段階 (1)、(2)、(3) に対応する変形の特徵を試験体ごとに考察する。 組物の各部材の振動台に対する相対変位を水平 1 ケ所、鉛直 2 ケ所で測定 し、水平变位と回転角を求めた。各段階 (1)〜(3) に対応する 4 秒間 $(1 / 10$ 周期）を選出し、組物の変形角 $\theta$ の変化に対する各部材の水平変位の変化 の割合を求めた。また、部材の水平变位の要素を、回転と滑りに分けた。 回転による水平変位は、部材の回転角と水平変位の測定点の高さから算出

し、実測による水平変位との差を部材どうしの滑りとした（図ー7）ただ し、部材の変形は無視できるものとした。図一 7 に各部材の「 $\mathrm{a}^{\prime}{ }_{\mathrm{n}}(\mathrm{n}=$ (1)〜(3)」の算出結果を示した。

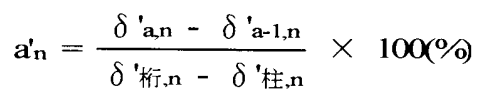

上式は第 $\mathrm{n} \mathbf{E}$ 階（ $\mathrm{n}=$ (1) (3)）に対応する 1/10 周期（4秒）間における $\mathrm{a}_{\mathrm{n}}^{\prime}$ : 部材 $\mathrm{a}$ の相対変位の増分が組物の変形角の増分に占める割合 $\delta^{\prime}{ }_{a, n}:$ 部材 $\mathrm{a}$ の水平変位（振動台との相対変位）の増分 

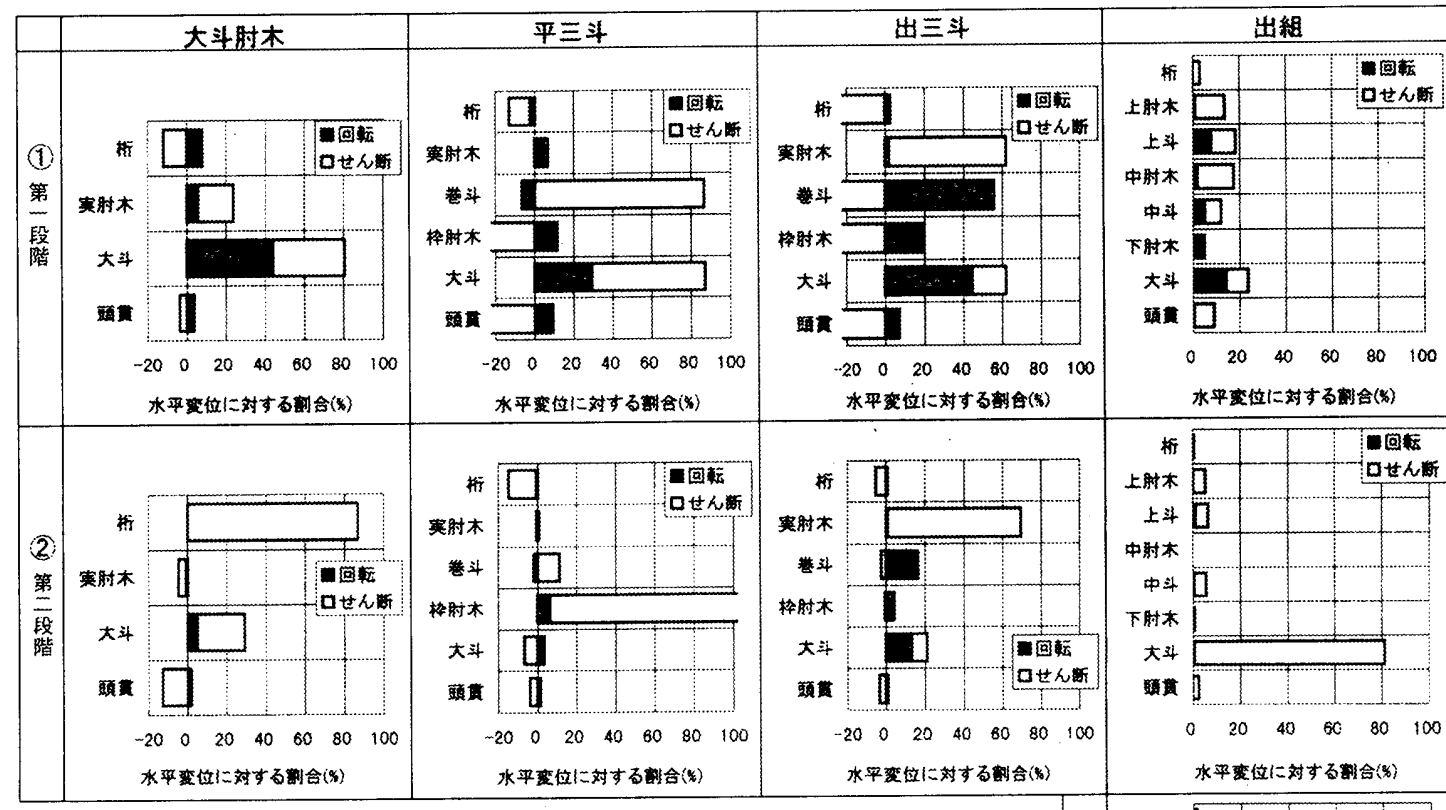

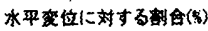
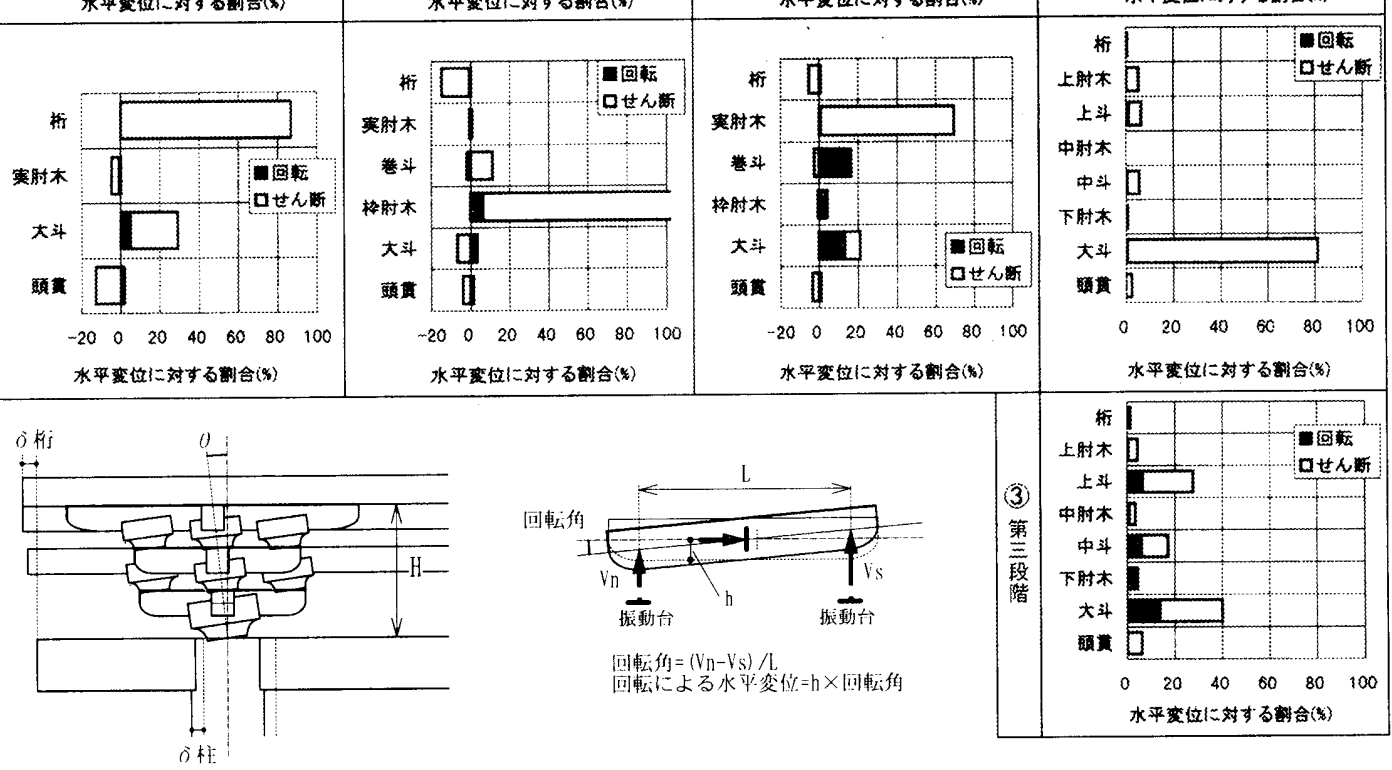

図-7 各部材の変位が全体の水平変位に占める割合と值の算出方法

$\delta_{\mathrm{a}-1, \mathrm{n}}$ : a の一つ下の部材の水平変位（振動台との相対変位）の増分 $\delta^{\prime}{ }_{\text {析 } \mathrm{n}}$ : 桁の水平変位（振動台との相対変位）の増分

$\delta^{\prime}$ 拉 $\mathrm{n}$ : 柱の水平変位（振動台との相対変位）の増分

組物試験体の各段階（11〜(3) での変形の特徵は以下のとおりである。 第一段階（1） $\mathrm{O} \Leftrightarrow \mathrm{A} ）$ : 平三斗を例外にして、大斗・巻斗の水平変位が主 要な変形の要素であり、その 50〜80\%は部材の回転による変位である。 第二段階（2） $\mathrm{A} \Leftrightarrow \mathrm{B} ）$ : 部材どうしの滑りが主要な変形の要素である。滑 る部材は試験体によって異なるが、一つの部材の滑りが全体の水平変位の 70 100\%を占めている。

第三段階 (3) $\mathrm{B} \rightarrow \mathrm{C}$ ) : 大斗・巻斗 (中斗と上斗) の水平変位が主要な変 形の要素である。斗の水平変位の 60 70\%は滑りによる水平変位である。

\section{7. 剛陮の算出}

履歴モデルの剛性を理論的に算出するために、実験結果をもとに対応す る変形の要素を以下のように仮定した（図一8）。

(1)大斗・斗の底面のめり込みによる回転: $\mathrm{K}_{1}=\Sigma$ 大斗・斗の底面のめり込 み剛性（三角変位めり込み）

(2)摩擦を伴う部材間の滑り : $\mathrm{K}_{2}=0$

(3)ダボのめり込みによる大斗・斗の移動: $\mathrm{K}_{3}=\Sigma$ 大斗・斗のダボのめり込 み剛性（三角変位めり込み）

ただし、木材は異方性があり繊維方向の岡性は䋊維直交方向のそれの 20 倍〜30 倍である。これより、縉維方向と繊維直交方向の部材の組合せの場 合、繊維方向のめり込みは無視できるものとする。

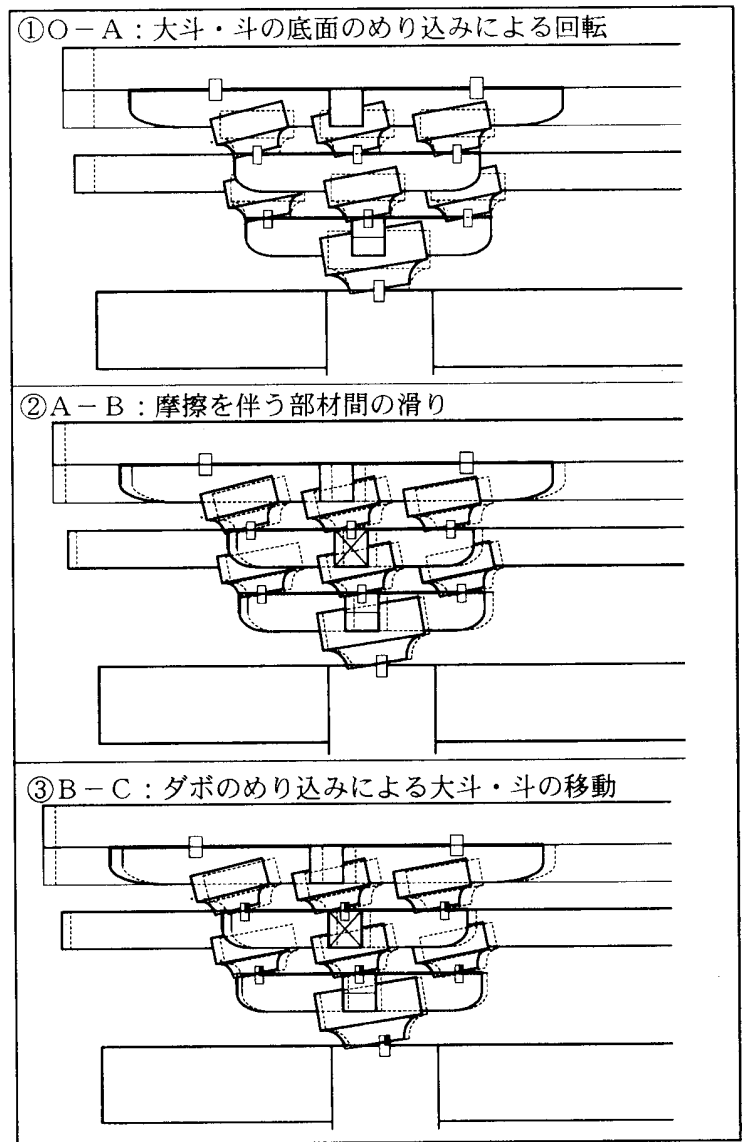

図-8 出組の変形状態 


\section{7-1 第一㓯性: $K_{1}$ (1) $\left.O \Leftrightarrow A\right)$}

組物試験体の第一剛性は大斗・斗の底面のめり込み剛性（三角変位めり 込み) の総和とし (図一9)、剛性の算出には以下の仮定を用いた。

1. 第2段階で、大斗・斗が水平に滑っていることが観測されていること より、ダボと大斗・斗のホゾ穴の間にはすき間があり、且つ回転は十分微 少であるとし、ダボは水平力に抵抗しないものとする。

2. 目視より、頭貫と大斗の間にはすき間があることが確認されたことか

ら、大斗は柱とのみ接し、頭貫とは接していないものとする。

3. 大斗に対する柱のめり込みは無視できるものとする。

4. 斗底面と肘木のめり込み剛性は、緎維直交方向どうしであるため、そ のめり込み剛性は三角変位めり込みの直列バネとする。

5. 大斗・斗の回転中心は、底面中央とする。

6. 各部材のめり込み剛性の総和は、同じ層（高さ）は並列、上下は直列 に接続するものとする（図一 10 )。

7. 実験から(1)での詿験体の変形角は 1/500 rad，以内であるため、めり込 みは弾性範囲内であるとする。

8. 斗の上面は表面仕上げが粗く、目視から肘木下面との間にはすき間が あることが確認されたことから、大斗・斗上面と肘木下面のめり込みは無 視できるものとする。

9. 部材のせん断変形及び局所的な滑りの影響は無視できるものとする。

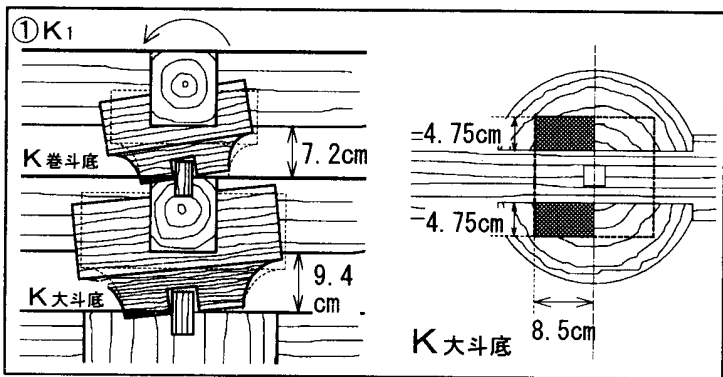

図-9 第一剛性（大斗・斗の底面のめり込み剛性）

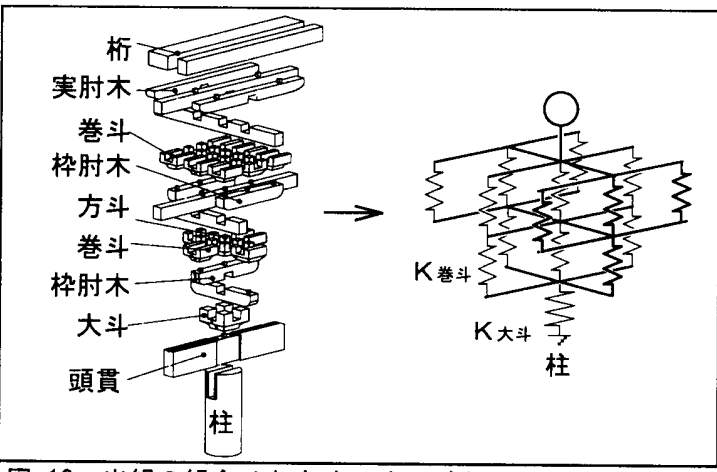

図-10 出組の組合せと大斗・斗のバネ

大斗、斗の形状は試験体によらず一定であるため、その弾性剛性及び弾 性限界変形角は、稲山の木材の三角变位めり込み理諭文 15 (注2）から次の ように求められる。

$\mathrm{K}_{\text {大斗底 }}=161($ tonf $/ \mathrm{rad}$. $)$

$\theta_{\text {大斗经 }}=1 / 110(\mathrm{rad}$.

$\mathrm{K}_{\text {巻斗底 }}=71.3($ tonf $/ \mathrm{rad})$

$\theta_{\text {巻斗庭 }}=1 / 101$ (rad.)

$\mathrm{K}_{\text {方斗底 }}=41.6(\mathrm{tonf} / \mathrm{rad})$

$\theta_{\text {方斗底 }}=1 / 100$ (rad.)

仮定 6 より組物一基分の岡性は出組の場合は（式 1 ）のように求められ る (図-10参照)。

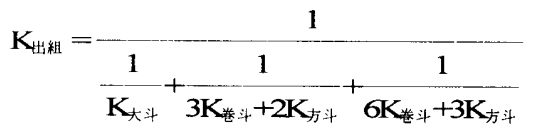

試験体は、組物 4 基が並列に接続しており、試験体全体の剛性は、上式 から求められた岡性の 4 倍とする。図一11に、めり込久剛性から算出した 試験体の弾性剛性（以降、理論值と記す）と、静的水平加力試験の荷重変 形関係から得られた接線剛性（図一中(1)〜(3)の接線）を示した。

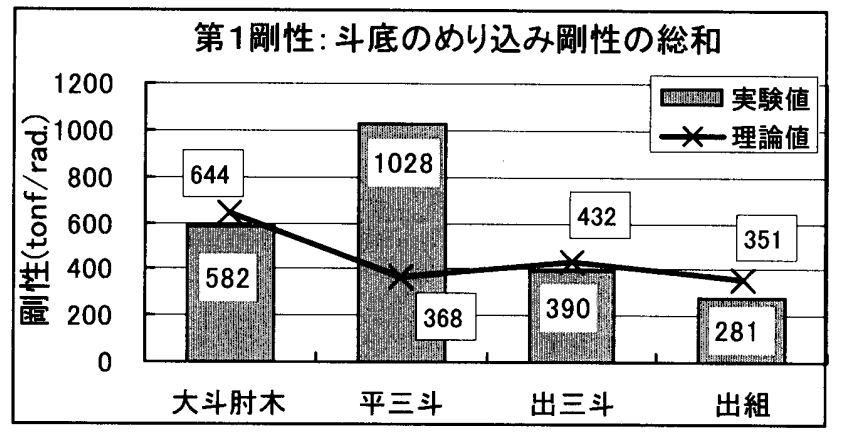

図-11 第一剛性 : 実験値と理論值の比較

平三斗以外は、理論值は実験值と良く一致しているが、理論值の方が若 干実験值を上回っている。「8，考察」の項で後述するように、この試験 体でのヤング係数が仮定值を上回っているとすれば、両者の剛性值の差は 更に開くことが想定できる。この原因としては、現在の仮定では、大斗・ 斗の底部の三角変位めり込みのみから剛性を算出しているが、実際には部 材のせん断変形、各接合部のめり込みなどの影響加ら剛性值が低くなって いると考えられる。また、平三斗における実験値と理論値の相違に関して は、予想していない部分での抵抗要素が働いた可能性、めり込み剛性を計 算する場合のパラメータ值が仮定した値と相違していた可能性等が考え られるが、今後更なる検討を要する。

以上より、試験体に用いた組物の第一剛性は、大斗と斗の底面の三角変 位めり込み岡性で概ね近似できることが分かる。ただし、回転の中心を大 斗・斗の底の中央としたが、積載荷重が増大すれば浮き上がりが拘束され る分、回転の中心はめり込み半径が大きくなる方に移動し、結果的にめり 込み剛性が大きくなることが想定される。本実験及ひ理論值は積載荷重 （0.5tonf／柱）は檜皮亘きに相当する場合である。

7-2 第二用性: $\mathrm{K}_{2}$ (2) $\mathrm{A} \Leftrightarrow \mathrm{B}$ )

部材どうしが水平に滑っているため、岡性 $\mathrm{K}_{2}=0$ とする。各試験体とも、 滑りが生じた水平荷重は概ね近い值（約 1 tonf）。表一1に各試験体の摩擦 係数の平均值と滑った部材を示す。

\section{表一1＼cjkstart試験体の摩擦係数と滑った箇所}

\begin{tabular}{|c|c|c|c|}
\hline \multirow{2}{*}{\begin{tabular}{|l} 
摩擦(静加力試験 \\
II-スDD
\end{tabular}} & \multicolumn{3}{|c|}{ 静摩擦·繰り返し加力の平均值 } \\
\hline & 摩擦力(tonf) & 摩擦係数 & 滑つた部材 \\
\hline K1 大斗肘木 & 1.1 & 0.55 & 桁 \\
\hline 平三斗 & 1.2 & 0.59 & 伜肘木 \\
\hline 出三斗 & 1.0 & 0.51 & 大斗 \\
\hline 出組 & 0.9 & 0.47 & 大斗 \\
\hline
\end{tabular}

摩擦保数は表面仕上げに依存するが、実験からそのばらつきは約 $20 \%$ あり、あまり大きくはない。滑った部材が圾験体によって異なる点などを 考慮すると、最も摩擦係数の小さい位置つまり滑りやすい位置で滑りが生 じたものと考えられる。滑る距離は、大斗肘木と平三斗はダボや仕口のな い(摩擦のみの) 層があるため、理論的には部材どうしが水平に離れるま で滑り続ける。出三斗と出組は、摩擦のみの層はなく、ダボ或いは相欠き 
によって接合されているため、滑る量は接合部のすき間の分であり、この 值は実験からは約 $4 \mathrm{~mm}$ であった。

\section{7-3 第三㓮性: $\mathrm{K}_{3}$ (3) $\mathrm{B} \rightarrow \mathrm{C}$ )}

試験体の第三剛性は大斗・斗の水平移動に伴うダボの三角変位めり込み 剛性の総和とした（図一12)。剛性の算出に当たり、以下の仮定を用いた。

1.ダボのめり込みは三角変位めり込みで近似できるものとする。

2.ダボのせん断変形は無視できるものとする。

3.ダボは第3段階ではじめてめり込むものと仮定し、試験体全体の変形 角が $1 / 30 \mathrm{rad}$ 程度の時に大斗、斗の回転角は凡之 $1 / 100 \mathrm{rad}$. であることか ら、ダボのめり込みは弾性範囲内であるとする。

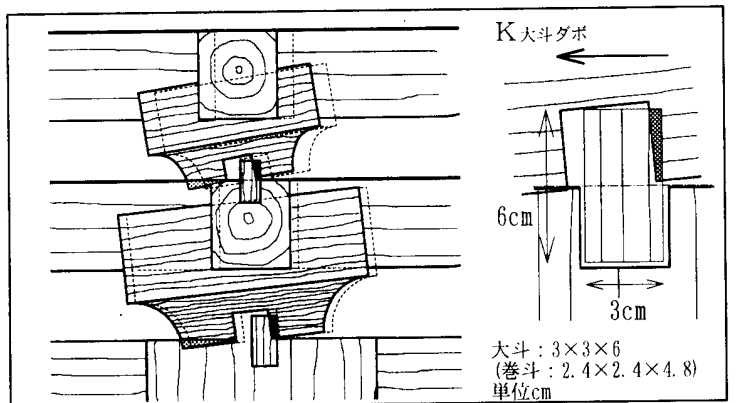

図-12 第三剛性（大斗・斗のダボのめり込み）

ダボのめり込み弾性剛性及び、弾性限界変形角は稲山の木材の三角変位 めり込み理論文15（注 3）から、次のように求められる。ただし、巻斗と方 斗のダボの形状は同じであり、材料定数等は第一剛性之同值を用いた。

$\mathrm{K}_{\text {大外多求 }}=18.0($ tonf $/ \mathrm{rad}$. $)$

$\theta_{\text {大汁多求 }}=1 / 111(\mathrm{rad}$ )

$\mathrm{K}_{\text {苍斗多类 }}=11.5$ ( $\mathrm{tonf} / \mathrm{rad}$.)

$\theta_{\text {巻壮抹 }}=1 / 111(\mathrm{rad}$.

組物一基及び、試験体全体の剛性は第一岡性と同様に求められる。実験 から得られた接線岡性とダボのめり込みから算出した理論剛性を図ー13 に示した。理論値と実験值は比較的良く一致していることが分かる。

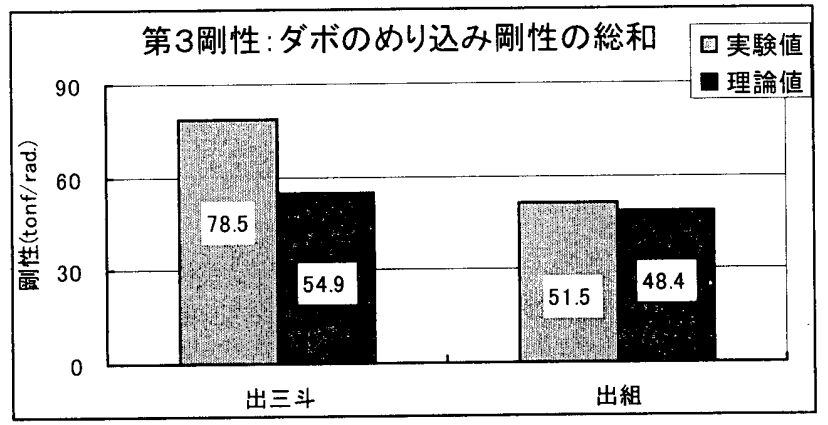

図-13 第三剛性

\section{7-4 剛性の組合せ}

第一剛性 $\left(\mathrm{K}_{1}\right)$ と第三剛性 $\left(\mathrm{K}_{3}\right)$ の関倸は、図-14 のように摩擦要素 を介した直列バネとしている。(1)では部材間、特にダボとダボ穴の間にす き間があるため、ダボは変形せず、剛性は $\mathrm{K}_{1}$ のみで決まるが、(2)で髇りが 生じ部材間のすき間が吸収される。従って実際には(3)では、 $K_{1}$ と $K_{3}$ の直列 バネの值になるが、 $K_{1} \gg K_{3}$ であるためここでは、(3)は $K_{3}$ とした。

\begin{tabular}{|c|c|}
\hline 初期状熊 $\mathrm{K}_{1}$ & 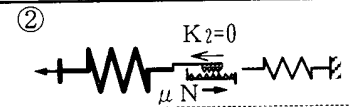 \\
\hline 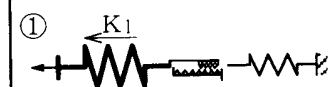 & 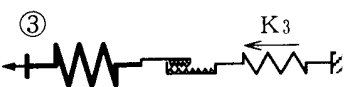 \\
\hline
\end{tabular}

\section{8. 考察}

組物を摩擦要素を介して木材のめり込みバネが直列に接続したモデル と仮定すると、全体の変形角は $1 / 30 \mathrm{rad}$. に達しても、各バネの変形は 1/100rad. 程度であり、弾性範囲内であると考えられる。従って、繰り返 し加振に対して剛性が低下しないという組物の荷重変位関係の特徵は、滑 りによる変形及び滑り要素を介して変形が集中しないことにより、試験体 全体は大変形に達しても、各要素レベルは弾性範囲であることに起因して いるといえる。

任意の組物に関して、第一岡性については大斗・斗の寸法と数、第二岡 性は摩擦係数、第三剛性は夕゙ボの数と寸法が与えられれば、その岡性と履 歴形状を推定することができるようなモデルを提案した。各パラメータに つては以下の点に留意が必要である。摩擦保数は、材料・表面仕上げ・ 含水率などの影響を受ける值である。しかし、組物は複数の部材が積層し て構成されていることから、罗も低い摩擦係数の位置で滑りが生じている。 つまり、摩擦保数の下限值が分かれば良い。ヤング係数は文献 16 から求 めているが、実験で使用した材料は、文化財建造物に使用されるような優 良な材料であるため、一般の建物で使用されている材料にもとづいて定め られた文献文16の值よりも、高い值を示すことが想定できる。めり込办剛 性は、ヤング倸数に比例するため、理論值はここで示した值よりも高くな ると推測できる。第一岡性と第三岡性の槃がり方（図ー13）は、摩擦要素 を介した直列バネであり、このギャップは部材間、特にダボとダボ穴のす き間または部材間のガ夕の総量であり、施工精度・老朽化などと密接に関 係した值である。この值は、実験值からは $4 \mathrm{~mm}$ 程度と得られているが、既 存の建造物の場合は定量化が困難であり、建物の老朽化による影響と共に 今後の重要な検討課題である。

この履歴モデルは 4 種類各 1 体の試験体の実験結果を根拠としている ため、その一般性には限界があるといえる。今後はより多くの種類・大き さの組物を対象とした実験を行い、モデルの妥当性の検討を行う必要があ る。特に、本実験での最大変形角は約 $1 / 30 \mathrm{rad}$. であり、これ以上変形が進 んだ際の情報がない。更に、除荷時の剛性に関する検討も含め今後の検討 課題である。

\section{9. 結論}

伝統的木造建築に用いられる、組物 4 体の実物大の部分模型を対象とし た静的水平加力試験から組物の復元力特性及び各剛性に対応する変形の 特徵を考察した。異なる 4 種類の組物の共通の特徵より、マルチリニア型 の履歴モデルを提案し、剛性を木材のめり込み理論から算出した。実験結 果之理論値の比較から、組物の剛性をその形状・材料特性から推定する方 法を提案した。

本研究で得られた結論は以下のとおりである。

・組物は繰返し加力に対して剛性の低下が認められない。これは、部材ど うしの滑りによる変形及び滑り要素を介して変形が集中しないことによ り組物全体が大変形に達しても、各要素レベルでは弾性範囲であることに 起因している。

·静的水平加力試験より組物の荷重変位履歴曲線は、複数の折線 (1)〜3) で近似できる、マルチリニア型の復元力特性を示す。

・履歴モデルの3つの岡性に対応する組物の主要な変形の要素は(1)大斗・ 巻斗の回転、2部材どうしの滑りー(3)大斗・巻斗の滑りである。

・3つの岡性はそれぞれ、(1)大斗・巻斗底面のめり込夕剛性の総和、(2)滑 りであるため0、3大斗・巻斗のダボのめり込み剛性の総和、から理論 
的に算出したところ、実験値と良く一致する。

・上記の事項に基づいて、応答解析が可能な組物のマルチリニア型の履歴 モデルを提案した。

今後は、この履歴モデルを用いた地震応答解析を行い振動台加振試験結 果との比較から、モデルの妥当性を検証する。

\section{謝辞}

文化庁建造物課清水真一博士、（財）文化財建造物保存技術協会安田一男 氏、京都大学西澤英和博士にご指導賜りました。また、実験では近藤信輔 氏、亀山央樹氏、近藤哲氏をはじめとする東京大学大学院坂本研究室の大 学院生にお世話になりました。ここに記して謝意を表します。

\section{注記}

（注 1) 試験体の単位重量は、試験片 3体の計浿値 (413kgW/m? $\left.419 \mathrm{kgw} / \mathrm{m}^{3}, 464 \mathrm{kgw} / \mathrm{m}^{3}\right)$ の平均値。含水率は、試験体の 20 箅所を木材水分計 (ターク H, Kett Elect ric Laboratoy 製）で計測した值（最小 10.2\%、最大 14. 8\%）の平均値とした。

(注2) 木材の三角変位吅込み（弾性範囲）の弾性限界变形角 $\theta_{v}$ ，任意の変形角 $\theta$ に対するモーメントMは下式から求められる文。

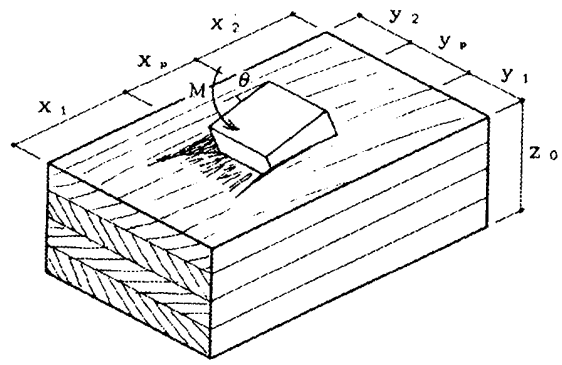

$$
\theta_{v}=\frac{z_{o} f_{m}}{x_{p} E_{\perp} \sqrt{C_{x} C_{y} C_{x m} C_{y m}}} \quad M=\frac{x_{p 3} y_{p} C_{y} E_{\perp} \theta}{z_{o}}\left(C_{x d}+\frac{1}{3}\right)
$$

剛性 : $\mathrm{K}=\mathrm{M} / \theta$ とした。

各補正係数は下式から求められるが、詳紐は文15を参照。

$$
\begin{aligned}
& C_{x}=1+\left[\Phi\left(\frac{2 x_{1}}{z_{o}}\right)+\Phi\left(\frac{2 x_{2}}{z_{o}}\right)-1\right] /\left(\frac{0.8 x_{p}}{z_{o}}\right) \\
& C_{y}=1+\left[\Phi\left(\frac{2 n y_{1}}{z_{o}}\right)+\Phi\left(\frac{2 n y_{2}}{z_{o}}\right)-1\right] /\left(\frac{0.8 n y_{p}}{z_{o}}\right) \\
& C_{x m}=1+\frac{z_{o}}{0.8 x_{p}} \quad C_{y m}=1+\frac{z_{o}}{0.8 n y_{p}}
\end{aligned}
$$

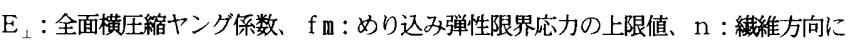
対する絊維と直交方向の近似値間倍率（木材のポアソン比の異方性を修正して等方性 弾性体に近似置換するための倍率。㬰験結果から $\mathrm{n}=5 \sim 7)$ 女 $15 。 \Phi(\mathrm{x})$ : 標準正規確率 変量。

なお、計算にあたって係数は標準的值である次の值を用いた。

$E_{L}=4.0\left(\right.$ tonf $\left./ \mathrm{cm}^{2}\right), \mathrm{f}_{\mathrm{a}}=0.075\left(\right.$ tonf $\left./ \mathrm{cm}^{2}\right), \mathrm{n}=6$

（注 3）大斗，巻斗，方斗は水平移動するが，第一段階て回転し角度がついているた め, ダボのめり込み形状は三角変位であると仮定した。

\section{参考文献}

1) 光井渉：地震被害と文化財建造物、月刊文化財、第一法規出版株式会社、 p. 13、平 成 8 年 2 月

2 ) Ryo Tanabashi : Earthquake Resistance of Traditional Japanese Hooden Structures. Proc. of the Second World Conference on Earthquake Engineering (Special Lecture)、pp, 180-181、1960 年 7月
3) 山辺克好、金井清 : 五重塔の甪震性に関する研究、日本大学生産工学部報告（第 21 巻第 2 号)、pp. 91-110、1988 年 12 月

4) 坂静雄 : 金堂構造の安全度判定に関する研究（第八報 社寺骨組の力学研究 第四 部法隆寺金堂内陣架構 $1 / 2$ 模型の引倒し抗力及復原力)、文化庁保存修理課、昭和 19 年 4 月

5) 坂静雄: 社寺骨組の力学的研究 (第 1 部 柱の安定復原力)、建築学会大会論文集、 pp. 252-258、昭和 16 年 4 月

6) 西澤英和：伝統的木構造の耐震性に関する基礎研究（斗供及び小壁の力学特性につ (U)、京都大学建築学科、1996 年3月

7) 山田憲明・西澤英和: 2 方向の地震力を受ける立体架構の動的応答解析（伝統的木 構造の地震応答解析)、京都大学工学部建築第二学科 1996 年度卒業論文、1997 年 3 月

8) 林知行、軽部正彦: 古代伝統木造架構の実大水平加力実験（その 1 概要と斗組架 構実駼）（その2 実大架構実験と履㐩性状）、日本建筑学会大会学術講演梗概集、 pp. 269-270、1998 年 9 月

9) 坂本功・大橋好光・本村正彦・藤田香織・安田一男・川久保政茂: 伝統的木造建筑 の組物の振動台実験（その 1 概要と静加力試験）、1997 年度日本建築学会関東 支部研究報告集、pp. 37-40、1998 年 3 月

10) 木村正彦・藤田香織・坂本功・大橋好光・川久保政茂・安田一男: 伝統的木造建筑 の組物の振動台実験（その2 組物の振動特性）、1997 年度日本建築学会関東支 部研究会、pp. 41-44、1998 年 3 月

11) 藤田香織・ 木村正彦・大橋好光・坂本功 : 伝統的木造建築の組物の振動台実験（そ の 3 地震波加振)、日本建築学会大会学術講演梗概集、pp. 263-264、1998 年 9 月

12) 木村正彦・大橋好光・藤田香織・坂本功 : 伝統的木造建筑の組物の振動台実験（そ の 4 組物の上下振動特性)、日本建築学会大会学術講演梗概集、pp. 265-266.1998 年 9 月

13) 藤田香織・木村正彦・大橋好光・坂本功 : 伝統的木造建築の組物の振動台実験（そ の5 出組の静加力試験）、日本建築学会大会学術講演梗概集、pp. 15-160、1999 年 9 月

14) Kaori Fujita. Isao Sakamoto, et. al. : Static and Dynamic Loading Tests of Bracket Complexes used in Traditional Timber Structures in Japan. 12WCEE. 2000. 1

15）稲山正弘：木材のめり込み理論とその応用（勒性に期待した木質ラーメン接合部 の而震設計法に関する研究、東京大学学位論文、1999.12

16) 日本建築学会: 木質構造設計規潐・同解説、第 2 版第 1 刷、（社）日本建築学会 丸善、p. 17、1995. 1

(2000年 5 月10日愿稿受理，2000年12月21日採用決定) 